\title{
The Legality of Charity Poker in North Carolina
}

\author{
BLAKE GRIFFIN \\ $\&$ \\ BARBARA OSBORNE \\ University of North Carolina - Chapel Hill
}

\section{INTRODUCTION}

For more than a thousand years, people have enjoyed playing a card game called poker. A combination of luck, skill, tenacity, fortitude, strategy and acting no doubt contribute to the game's lingering popularity. Friends gathered at home or a bar may play a friendly game, while others may test their skills in high stakes games at casinos. Increasingly, charitable organizations are using poker tournaments as fundraisers for their worthy causes.

In North Carolina, the ability of poker players to play "at home, in bars or taverns, and even at charity events"1 has increasingly come into question. While the state of North Carolina's Department of Alcohol Law Enforcement has infiltrated sophisticated gambling operations in North Carolina involving poker games, ${ }^{2}$ some state prosecutors have opted to turn a blind eye to poker

1. Mission Statement, http://pokerplayersalliance.org/pdf/PPAMissionStatement.pdf (last visited March 1, 2009).

2. See Estes Thompson, Poker Champ Netted in NC Gambling Bust, Associated PREss, Sept. 11, 2007, available at http://www.pokerplayersalliance.org/news/newsandarticles_article. php?DID=254; see also Thomasi McDonald, Casino Raid Netted Big Poker Winner, THE NEws \& OBSERVER, Sept. 11, 2007, available at http://www.newsobserver.com/ news/crime safety/story/699914.html (last visited March 1, 2009). 
tournaments run in bars and restaurants or for charitable purposes. ${ }^{3}$ Questions regarding the legality of hosting charitable fundraisers with a Texas Hold'Em poker format have caused organizations such as Rocky Top Hospitalities, who recently staged a Texas Hold'Em tournament at one of their restaurants, to approach the North Carolina Alcohol Law Enforcement before hosting such events in order to verify their legality. ${ }^{4}$ Other organizations, such as Nourish International, ${ }^{5}$ have staged large scale Texas Hold'Em tournaments on college campuses to raise money for worthy causes. ${ }^{6}$ However, according to the North Carolina Alcohol Law Enforcement ${ }^{7}$ and recent North Carolina case law, ${ }^{8}$ these organizations may be violating the law.

To complicate matters for poker advocates in North Carolina, the issue of whether poker is a game of skill or game of chance was recently litigated in Joker Club, L.L.C. v. Hardin ${ }^{9}$ (hereinafter "Joker Club") where the state's Court of Appeals affirmed an order of the Durham County Superior Court denying injunctive relief sought by Joker Club, L.L.C. ("Joker Club") in order to open a poker club in Durham County. ${ }^{10}$ In its appeal, Joker Club sought a determination by the Court of Appeals that "poker was a game of skill, as opposed to a game of chance, and thus not in violation of N.C. Gen. Stat. §14292 (2005)."11 Much to the chagrin of poker advocates in North Carolina, ${ }^{12}$ the North Carolina Court of Appeals ruled against Joker Club, ultimately ending its hopes of opening a legal poker club within the borders of North Carolina.

3. See Thomasi McDonald, Casino Raid Netted Big Poker Winner, THE NEWS \& OBSERVER, Sept. 1 1, 2007, available at http://www.newsobserver.com/news/crime_safety/story/699914.html (last visited March 1, 2009).

4. Id.

5. For more information on Nourish International, see Nourish International, http://www.nourishinternational.org/about/index.php (last visited March 1, 2009).

6. See Aaron Fiedler, Students Chip In for Poverty, THE DAILY TAR HEEL, March 30, 2007, available at http://media.www.dailytarheel.com/media/storage/paper885/ncws/2007/03/30/ University/Students.Chip.In.For.Poverty.Relief-2814204.shtml.

7. North Carolina Alcohol Law Enforcement director Mike Robertson told the Raleigh News \& Observer that if "there was an exchange of cash or other prizes ... then the tournament was illegal." McDonald, supra note 3.

8. See generally Joker Club, L.L.C. v. Hardin, 643 S.E.2d 626 (N.C. App. 2007).

9. 643 S.E.2d 626.

10. Id. at 627 .

11. Id.

12. See McDonald, supra note 3 (referencing several North Carolina poker players' disgust at the current state of North Carolina gambling law). 
Although poker may be played in homes, bars, restaurants, casinos, and even on the Internet, this article will focus solely on the legality of charitable poker tournaments in North Carolina. First, a brief history of the game of poker is provided. Then, the state of gambling law as applied to poker, and specifically the Texas Hold'Em variant in North Carolina under N.C. Gen. Stat. $\$ 14-292$, will be examined. ${ }^{13}$ Additionally, the application of North Carolina case law to charitable poker tournaments will be discussed using the Hold'Em for Hunger charity tournament as an example. This paper concludes that such events, in their current forms, violate N.C. Gen. Stat. §14-292.

\section{HISTORY OF POKER}

Although, scholars have debated over the exact origins of poker, ${ }^{14}$ many cultures have influenced the game. ${ }^{15}$ Card games such as Âs Nâs from Persia as well as Poque ${ }^{16}$ and Bouillotte from France have been credited as the most "immediate ancestors" of poker. ${ }^{17}$ Additionally, Poque and Germany's Pochspiel, ${ }^{18}$ were descendants of a Spanish card game known as Primero, ${ }^{19}$ in which bluffing techniques were "an integral part of the game." 20 The British game, known as "Brag" was also popular in American colonies and involved "bluffing and wild cards."21 Throughout its history, poker has evolved from these early forms of card games involving bluffing, wild cards, and simple wagers, into a myriad of variations. ${ }^{22}$

13. N.C. GEN. STAT. § 14-292 (2005).

14. Michael Dummet, The Game of Tarot: From Ferrara to Salt lake City 45-51 (1980); see also DAVID PARLETT, THE OXFORD GUIDE TO CARD GAMES 111-13 (1990).

15. Id. See also Frank Wallace, Poker: A GuaranteEd InCOME For Life By using the ADVANCED CONCEPTS OF POKER 179-82 (1968) (detailing the origins of the game and suggesting that poker descended from the Persian game Âs Nâs).

16. Jack Kelly, Poker: The Very American Career of the Card Game You Can Learn in 10 minutes and Work on for the Rest of Your Life, 57 AMERICAN HERITAGE 38, available at http://www.americanheritage.com/entertainment/articles/web/20061219-poker-gambling.shtml (last visited March 1, 2009).

17. See David Parlett, The Oxford Guide to Card Games 111-13 (1990).

18. See Kelly, supra note 16.

19. Id.

20. Id.

21. Id.

22. See The History of Poker, Poker.com, http:/www.poker.com/history-of-poker.htm (last visited March 1, 2009) (discussing the "games that have, in turn, dominated the modern poker scene" and providing other variations). 
The origin of poker in the United States, as we now know it, is generally accepted as having its roots in New Orleans. ${ }^{23}$ When French-Canadian settlers founded New Orleans, they brought with them their card games such as poque. ${ }^{24}$ Following the Louisiana Purchase of 1803 , the game of poker began to spread throughout the United States by way of the Mississippi River. ${ }^{25}$ Throughout the $19^{\text {th }}$ century, the Mississippi River and the riverboat culture increased the presence and prominence of poker throughout the United States by allowing increased mobility for gamblers. ${ }^{26}$

While poker and its influence on American culture were confined to the southern and western regions of the United States during the early and midnineteenth century, ${ }^{27}$ the game achieved broader popularity by the Civil War. ${ }^{28}$ Poker became a favorite past-time for soldiers in both the Union and Confederate armies. ${ }^{29}$ Following the Civil War, veterans moving west in search of peace and prosperity spread the game to the frontier. ${ }^{30}$ With the increased popularity of poker and the movement of the game throughout the country, poker evolved into different forms depending on the region in which it was played. ${ }^{31}$ During World War II, the armed forces spread and popularized poker throughout the world. ${ }^{32}$ Eventually, poker would become so rooted in American culture that pundits used its terms and phrases to describe Cold War tactics of the United States and their Soviet counterparts. ${ }^{33}$

23. See Anthony Cabot \& Robert Hannum, Poker: Public Policy, Law, Mathematics, and the Future of an American Tradition, 22 T.M. COOLEY L. REV. 443, 448 (2005); See also ALFRED Alvarez, PoKer: Bets, BluffS, AND BAD BeATs 32 (2001).

24. See AlVAREZ, supra note 23 , at 32 .

25. Id.; see also Kelly, supra note 16.

26. See Kelly, supra note 16 . "Poker's early days are closely linked to the riverboat gambler. This American fixture began as a cardsharp preying on the boat crews that emerged from the interior. He soon moved onto the river himself ..." Id.

27. Id. One of the first mentions of poker in print was in 1837 by James Hildreth in Dragoon Campaigns to the Rocky Mountains. Hildreth noted in his work that poker was "'a favorite game of cards at the south and west.' " Kelly, supra note 16. See also PARLETT, supra note 17, at 111 (stating that poker "is first mentioned in print in 1836, in Dragoon Campaigns to the Rocky Mountains").

28. Kelly, supra note 16.

29. Id:; see also The History of Poker, supra note 22 ("It was extremely popular during the Civil War when the soldiers of both armies played").

30. See Kelly, supra note 16.

31. Id. For example, the modern day poker hand known as a straight "was listed as a regional variation in 1864 and its inclusion was optional even in the 1890s." This variation was most likely "listed" in The American Hoyle of 1864.

32. Id.

33. Id. As Kelly noted, 
Perhaps the most popular variation of poker ${ }^{34}$ has been "the fast-paced variant of Seven-Card Stud"35 known as Texas Hold'Em. Each player is dealt two cards (known as the player's "hole" cards or "pocket" cards) face down, which are used in combination with the five "community" cards placed face up on the table to make the best five-card hand. ${ }^{36}$ When played at a casino the dealer's position is represented by a plastic "button" with that player receiving the last card dealt and acting last during each round of betting. ${ }^{37}$ At the beginning of each hand, two players must post bets before they see their hand. ${ }^{38}$ The player to the left of the button (the small blind) must post a portion, usually half of the opening bet, while the player to the left of the small blind (the big blind) must post the full amount of the opening bet. ${ }^{39}$ These positions change with each hand and rotate clockwise around the table so that each player must post the small and big blinds. ${ }^{40}$

After the two hole cards are dealt and the blinds are posted, the rest of the players have three options. ${ }^{41}$ The player can "call" the opening bet by matching the big blind. ${ }^{42}$ The player may raise the pot, which forces other players to either match or increase their bet. ${ }^{43}$ Or the player may fold, ending their participation in the hand. ${ }^{44}$ After all bets are placed, three community cards are dealt face up, called the "flop," and another round of betting

during the Cold War, with the Americans and Soviets glaring at each other across the table and alternately tossing new ballistic missiles and nuclear bombs into the apocalyptic pot, poker analogies became a commonplace way of making sense of what some insisted was madness. Who was bluffing? Who had the better hand? Who was willing to raise the stakes?

'Today a new hand is being dealt in the cold war that is a game of cold poker between the Kremlin and the new Administration in Washington,' [Oskar] Morgenstem wrote in 1961. 'Something substantial can be learned from good poker principles.'

Id.

34. See Cabot \& Hannum, supra note 23 , at 452 (stating that "[t]he most popular type of poker played in 2005 was Texas Hold'Em").

35. Kelly, supra note 16.

36. Johnathan Grotenstein \& StORMS REBACK, All In: THE (Almost) ENTIRELy TruE STORY OF THE WORLD SERIES OF POKER 18-20 (2005).

37. Id.

38. Id.

39. Id.

40. Id.

41. See id.

42. Id.

43. Id.

44. Id. 
ensues. ${ }^{45}$ After the flop betting round ends, the dealer will deal a fourth card face up (called "fourth street" or "the turn") and a third round of betting begins. ${ }^{46}$ A final card is dealt (called "fifth street" or "the river") with a fourth round of betting. ${ }^{47}$ If a player bets and all others fold, that player wins the pot and is not required to show his or her cards. ${ }^{48}$ If two or more players remain, there is a showdown with each player using his or her two pocket cards and the five community cards to make the best five-card poker hand. ${ }^{49}$ If the best hand is shared by two players they split the pot; if the five community cards form the best hand, all players remaining share the pot. ${ }^{50}$

Texas Hold'Em, often termed the "Cadillac of poker," 51 is thought to have its roots in Corpus Christi, Texas. ${ }^{52}$ The origins of Texas Hold'Em's popularity have been traced back to the summer of 1949, when a "fabled poker game" 53 took place between Nick "the Greek" Dandolos and Johnny Moss at the Horseshoe casino in Las Vegas, Nevada. ${ }^{54}$ At the behest of Dandalos, Benny Binion, owner of the Horseshoe, arranged for the match to take place in the lobby of the casino. ${ }^{55}$ Astonishingly, the two gamblers played various forms of poker head-to-head over the next five months, ${ }^{56}$ with breaks only for sleep, ${ }^{57}$ ending only after Dandalos withdrew. ${ }^{58}$ Following the success of the game, Binion noted that the public had come to watch poker at his casino "with the fervor of dedicated sports fans." ${ }^{59}$ Eleven years later Binion decided

45. Id.

46. Id.

47. Id.

48. Poker Rules, Texas Hold 'Em http://www.pokerpages.com/pokerinfo/rules.htm?content= I\#texas (last visited March 22, 2009).

49. Id.

50. Id.

51. See The History of Poker, supra note 22.

52. See Kelly, supra note 16; see also, History of Texas Hold'Em, World Casino Directory, http://www.worldcasinodirectory.com/texasholdemhistory.htm (last visited March 1, 2009) (The game is said to have first come to Dallas, Texas, in 1925).

53. See Kelly, supra note 16.

54. Id.; see also, Alvarez, supra note 24 at 94-96; ANDY BELlin, POKER NATION: A HighStakes, Low-Life Adventure into the Heart of a Gambling Country 71-71 (2002); World Series of Poker History, World Series of Poker, http://espn.go.com/eoe/wsop/history.html (last visited March 1, 2009).

55. See BELLIN, supra note 54 , at 71-72.

56. See Alvarez, supra note 24, at 96 ; see also World Series of Poker History, supra note 54.

57. BELLIN, supra note 55 .

58. Id. at 72 .

59. World Series of Poker History, supra note 54. 
to capitalize on the interest generated by poker and stage the "World Series of Poker." 60 Although the first installments of the World Series of Poker met with "scant attention," ${ }^{61}$ once Binion established Texas Hold'Em as the focal game of the tournament, interest in poker began to swell. ${ }^{62}$

Although the beginning of Texas Hold'Em's popularity can be attributed to that 1949 marathon between Dandalos and Moss and Binion's keen business sense, the modern day Texas Hold'Em phenomenon may be attributable to more technological advances that have aided in popularizing the sport to the masses. In particular, the staging of a television series called "The World Poker Tour" has increased the ability of the masses to experience Texas Hold'Em poker. ${ }^{63}$ While poker was first broadcast in $1993,{ }^{64}$ it was not until 2002 that the game became viewer friendly, thanks to World Poker Tour's creator Steve Lipscomb and his use of embedded cameras in the poker tables to view player's dealt cards. ${ }^{65}$

Adding to the popularity of Texas Hold'Em has been the increased boom of the Internet and the advent and proliferation of online gambling websites. ${ }^{66}$ In 2005, an estimated 23 million Americans bet online. ${ }^{67}$ According to a 2006 survey of the casino entertainment industry by the American Gaming Association (AGA), one in five adults played poker in $2005 .{ }^{68}$ Of those players, "[o]ne in ten reported playing on the Internet for money."69

The popularity of poker has also been harnessed by charities for fundraising purposes. ${ }^{70}$ Generally, participants in a charity poker tournament

60. See Kelly, supra note 16.

61. Id.

62. See id.

63. See Kelly, supra note 16.

64. Josh Tyrangiel, Decks, Lies \& Videotape; With Cameras Peeking At Players' Cards--And Some Bizarre Contestants-Poker Is A Hot Spectator Sport, TIME, Sept. 1, 2003, at 62.

65. See id.

66. See Jeremy Evans, Growing or Declining?, TAHOE DAIly TRIBUNE, Nov. 15, 2007, available at $\mathrm{http}: / / \mathrm{www}$.tahoedailytribune.com/article/20071115/SPORTS/111150068 (discussing the relationship between attendance at the World Series of Poker and the Internet).

67. Frank Aherns, New Law Cripples Internet Gambling; Banks are Barred From Handling Transactions, WASH. POST, October 14, 2006, at A1.

68. See AmErican Gaming Ass'N, State of the States: The AGa Survey of Casino ENTERTAINMENT 21, http://www.americangaming.org/assets/files/2006_Survey_for_Web.pdf (last visited March 1, 2009).

69. Id. at 3 .

70. See Carolyn Kessel Steward, Cashing in when the chips are down: Charities, nonprofits ride the wave of poker popularity to raise money, METROWEST DAILY NEWS, March 5, 2006: see also 
pay a fee in order to play. The fees collected may be called a donation, and in fact the monies collected are used by the organization for charitable purposes. In exchange for the participation fee or donation, the player is given chips to bet. Players play and bet according to established Texas Hold'Em rules, but the players with the most chips at the end of the tournament may receive donated prizes or a set monetary amount, rather than the entire pot. ${ }^{71}$

The proliferation of charitable poker tournaments has continued to cause confusion among both the public and law enforcement officials across the country. Although participants in charity poker tournaments have a great time and contribute to a worthy cause, poker is gambling, and gambling in some form is prohibited by most states. Some states have opted to use discretion in prosecuting poker tournaments in the wake of confusion regarding the legality of poker within their state, ${ }^{72}$ while others have taken a more proactive stance on the issue and have sought to prevent poker within their borders, even for charitable purposes. ${ }^{73}$

Legal gambling prohibitions involving card games generally rely on a distinction within the law between games of skill and games of chance; challenges to poker prohibition have focused on this distinction as well. ${ }^{74}$ In particular, recent legal challenges and scholarly articles ${ }^{75}$ have weighed in on the issue of whether poker, specifically Texas Hold'Em, is a game where skill or chance predominates. ${ }^{76}$ The next section reviews the statutes that define

Jodi Rudoren, Seeking New Sources of Money, Charities Get In On Poker Craze, N.Y. TIMES, Feb. 6, 2006.

71. See Rudoren, supra note 73; see also Fiedler, supra note 6.

72. See Abigail Johnson, Know When To Hold 'Em; Prosecutor Exercises Discretion In Poker Prosecution, THE INDiANA LAWYER, May 17, 2006, at 1.; see also Thomasi McDonald, Poker Tourneys Gamble with Law, THE NEWS \& OBSERVER, Sept. 28, 2007, available at $\mathrm{http} / /$ www.newsobserver.com/front/story/719095.html (last visited March 1, 2009).

73. Radley Balko, Overkill: The Latest Trend In Policing, ChICAGo DaIly Law Bulletin, Feb. 8,2006 , at 6 .

74. See Joker Club, L.L.C. v. Hardin, 643 S.E.2d 626 (challenging N.C. GEN. STAT. § 14-292's applicability to the game of poker); Garrett v. State, 963 So. $2 \mathrm{~d} 700$ (Ala. Crim. App. 2007) (holding that poker is a game of chance under Alabama gambling laws).

75. See generally, Cabot \& Hannum, supra note 23 , at 459-65 (discussing the variation in state court's decisions regarding whether poker is a game of skill, a game of chance, or a game of mixed skill and chance); see also Michael A. Tselnik, Note: Check, Raise, Or Fold: Poker And The Unlawful Internet Gambling Enforcement Act, 35 HoFSTRA L. REV. 1617, 1619 (2007) (arguing that "there is no true difference between the skills and pitfalls involved in some forms of investing and some forms of gambling").

76. Advocacy groups, such as the Poker Players Alliance (PPA), have formed in order to generate support for the legalization of poker. According to their website, the 
gambling in the state of North Carolina, and case law that has shaped its interpretation.

\section{THE LEGAL STATE OF POKER IN NC}

The Tenth Amendment of the U.S. Constitution provides "the powers not delegated to the United States by the Constitution, nor prohibited by it to the States, are reserved to the States respectively, or to the people." ${ }^{177}$ The ability to regulate gambling is traditionally held by the state under the police power to protect the health, safety, and welfare of the public. ${ }^{78}$ In North Carolina, gambling has been illegal for at least 170 years. ${ }^{79}$ While the forms of gambling that have been acceptable have changed slightly during those 170 years of prohibition, ${ }^{80}$ the notion that gambling is associated with wagering or betting on a game of chance has remained consistent. ${ }^{81}$ Currently, North Carolina General Statute $\S 14-292$ provides in full:

Except as provided in Chapter $18 \mathrm{C}$ of the General Statues or in Part 2 of this article, any person or organization that operates any game of chance or any person who plays at or bets on any game of chance at

Poker Players Alliance (PPA) is a non-profit membership organization comprised of online and offline poker players. Our membership consists of enthusiasts from around the United States who have joined together to speak with one voice to promote the game and protect the right to play poker in all its forms. The PPA's mission is to establish favorable laws that provide poker players with a secure, safe and regulated place to play. Through education and awareness the PPA will keep this game of skill, one of America's oldest recreational activities, free from egregious government intervention and misguided laws.

Mission Statement, Poker Players Alliance, http://pokerplayersalliance.org/about/mission/ (last visited April 9, 2009).

77. U.S. CONST. amend. X.

78. See R. Scott Girdwood, Comment: Place Your Bets.. On The Keyboard: Are Internet Casinos Legal?, 25 CAMPBELL L. REV. 135 (2002).

79. See State v. Gupton, 30 N.C. 271,273 (Sup. Ct. 1848) (stating that "[t]he phrase, 'game of chance,' is not one long known in the law and having therein a settled signification, but was introduced into our statute book by the act of 1835."); see also, Jim Nesbitt, North Carolina Gambles Lottery Won't Fade Again, THE NEWS \& OBSERVER, March 30, 2006, available at http://www.newsobserver.com/701/story $/ 423350 . h t m l$ ("Spiritual revival and political and social reform were the motivations behind the 1834 law that banned public and private lotteries in North Carolina, one of 12 states to outlaw these games of chance in the $1830 \mathrm{~s} . . . ")$.

80. See Nesbit, supra note 86 (discussing the history of the lottery in North Carolina and its revival after more than 170 years of prohibition).

81. See State v. Gupton, 30 N.C. at 273. 
which any money, property or other thing of value is bet, whether the same be in stake or not, shall be guilty of a Class 2 misdemeanor. ${ }^{82}$

Chapter $18 \mathrm{C}$ of the North Carolina General Statutes regulates the North Carolina State Lottery. ${ }^{83}$ "Part 2 of this article" within N.C. Gen. Stat. §14292 refers to North Carolina's statutes regulating bingo and raffle games. ${ }^{84}$ Therefore, under North Carolina statutory law, the state sanctioned lottery, bingo, and raffles are exempted from North Carolina's statutory prohibition against "games of chance." 85

Additionally, North Carolina law prohibits the keeping of "any gaming table ... at which games of chance shall be played," 86 and both the "keeper" of the table as well as any person that plays or bets at an illegal table may be found guilty of a Class 2 misdemeanor. ${ }^{87}$ Allowing gambling in an "ordinary or other house of entertainment, or of a house wherein alcoholic beverages are retailed" is also a Class 2 misdemeanor in North Carolina. ${ }^{88}$ Taken together, these statutes criminalize individuals and organizations that either organize or play games of chance, ${ }^{89}$ the owners or "keepers" of gaming tables, ${ }^{90}$ and the owners or operators of the premises on which the gaming activities occur. ${ }^{91}$

What statutory law in North Carolina has left untouched, subsequent case law has aided in creating a discernable body of law that may be termed "North Carolina gambling law." While Joker Club is the latest case to deal with gambling law in North Carolina, case law on the topic dates back as far as 1848. ${ }^{92}$ In State v. Gupton, ${ }^{93}$ the Supreme Court of North Carolina set what other courts have termed the "classic summary of the law with respect to games of chance." 94

82. N.C. GEN. STAT. § 14-292 (2009).

83. See N.C. GEN. STAT. $\S \S 18 C-101$ - 18-172 (2009) (setting forth the North Carolina law regarding the state lottery).

84. See N.C. GEN. STAT. $\S \S 14-309.5$ - 14-309.15 (2009) (setting for the North Carolina law regarding bingo and raffle games).

85. See N.C. GEN. STAT. \$ 14-292.

86. N.C. GEN. STAT. $\$ 14-295$ (2009).

87. Id.

88. N.C. GEN. STAT. $§ 14-293$ (2009).

89. N.C. GEN. STAT. $\$ 14-292$.

90. N.C. GEN. STAT. \& 14-295.

91. N.C. GEN. STAT. \$ 14-293.

92. See Gupton, 30 N.C. 271.

93. Id.

94. Joker Club, 643 S.E.2d at 629. 
In an opinion written by Supreme Court Chief Justice Thomas Ruffin, the court defined what constitutes a "game of chance" in North Carolina gambling law. ${ }^{95}$ In ruling on whether the game of "ten pins" 96 was a game of skill or a game of chance, Justice Ruffin wrote that "the universal acceptation of 'a game of chance' is such a game, as is determined entirely or in part by lot or mere luck, and in which judgment, practice, skill, or adroitness have honestly no office at all, or are they the warted [sic] by chance." 97 Somewhat prophetic was his next statement. In providing an example for what he believed to be games of chance, Justice Ruffin stated that "games with dice which are determined by throwing only, and those, in which the throw of the dice regulates the play, or the hand at cards depends upon a dealing with the face down, exhibit the two [sic] classes of games of chance." 98 Justice Ruffin then provided his definition of what constitutes a game of skill by stating that "[a] game of skill, on the other hand, is one, in which nothing is left to chance, but superior knowledge and attention, or superior strength, agility, and practice, gain the victory." 99 While Justice Ruffin acknowledged that superior skill "is not always successful" his opinion "also makes clear that while all games have elements of chance, games which can be determined by superior skill are not games of chance."100 Justice Ruffin used the games of "chess, draughts or chequers, billiards, fives, bowles, and quoits," 101 as examples of games of skill that are not turned into games of chance merely by an element of chance being present. In particular, Ruffin noted that while games of skill may be subject to unforeseen occurrences, as when "an oversight, to which the most skilful is subject, gives an adversary the advantage; or an unexpected puff of wind, or an unseen gravel in the way, may turn aside a quoit or a ball and make it come short of the aim," 102 such unexpected or unforeseen occurrences, whether they be the fault of the player or of natural circumstances, does not turn a game of skill into a game of chance. ${ }^{103}$

95. See Gupton, 30 N.C. at 273-74.

96. "Ten pins" seems to be a game similar to modern day bowling. Id. at 275 ("We take this game to be one species of the game known in England. . . under the general term of Bowls....").

97. See Id. at 273-74.

98. Id. at 274 (emphasis added).

99. Id.

100. Joker Club, 643 S.E.2d at 630.

101. Gupton, 30 N.C. at 274.

102. Id.

103. See id. ("Inattention is the party's fault, and not his luck; and the other obstacles, though not perceived nor anticipated, are occurrences in the course of nature and not chances.") Id. 
Almost half-a-century later, the concept of a "game of chance" in relation to North Carolina gambling law would again be examined, this time in the context of card games. ${ }^{104}$ In State v. Taylor, ${ }^{105}$ the Supreme Court of North Carolina ruled on the issue of whether or not a game of cards was a game of chance. ${ }^{106}$ In Taylor, two men engaged in a card game prompted by one of the defendants boasting that he could "beat any man a game of five up for twentyfive cents." 107 In determining that the defendants were guilty of violating the law, Justice Avery reinforced Chief Justice Ruffin's precedent in Gupton and expanded Ruffin's definition of a "game of chance" to include games played with "ordinary playing cards." 108 In particular, Justice Avery bolstered the notion that card games invariably involved more chance than skill by stating:

It is a matter of universal knowledge that no game played with ordinary playing cards is unattended with risk, whatever may be the skill, experience or intelligence of the gamesters engaged in it. From the very nature of such games, where cards must be drawn by and dealt out to players, who cannot anticipate what ones may be received by each, the order in which they will be placed or the effect of a given play or mode of playing, there must be unavoidable uncertainty [sic] as to the results. ${ }^{109}$

After distinguishing the facts of the instant case from those of Gupton, Justice Avery held on appeal that Taylor's conviction for betting money on a game of chance would stand. ${ }^{110}$

Drawing from the decisions in Gupton and Taylor, North Carolina gambling law began to tinker with the fine line between games of chance or games of skill, culminating most prominently in the 1953 case of State $v$. Stroupe. ${ }^{111}$ In Stroupe, the Supreme Court of North Carolina heard a challenge to the defendant's contention that a certain form of billiards, known as "Negro Pool"112 was a game of skill and not a game of chance, and

104. See State v. Taylor, 111 N.C. 680 (Sup. Ct. 1892).

105. Id.

106. Id.

107. Id. at 682 .

108. Id.

109. Id. at 681-82.

110. Id.

111. 238 N.C. 34 (Sup. Ct. 1953).

112. Id. at 39. The court in Stroupe describes "Negro Pool" as follows:

A flat board with holes in it is placed at one end of the table. A picture of two Negroes is at one hole; a picture of one Negro at another hole. The holes are numbered. Each player draws a pill 
therefore not in violation of N.C. Gen. Stat. §14-292. ${ }^{113}$ Although the court ultimately awarded the defendants a new trial based on prejudicial jury instructions, ${ }^{114}$ the court's analysis of the inquiry a court must make in determining whether a game is a game of chance or a game of skill has become the applicable test used in subsequent case law. ${ }^{115}$ In determining that "Negro Pool" was a game of chance, ${ }^{116}$ the Stroupe Court stated the applicable test for determining whether a certain type of pool is one of chance or skill in North Carolina as follows:

[T] he test of the character of any kind of a game of pool as to whether it is a game of chance or a game of skill is not whether it contains an element of chance or an element of skill, but which of these is the dominating element that determines the result of the game, to be found from the facts of each particular kind of game. Or to speak alternatively, whether or not the element of chance is present in such a manner as to thwart the exercise of skill or judgment. ${ }^{117}$

This test, based on the predominant element of either chance or skill within a particular game, has been referred to in legal scholarship as the "predominance test."118 This "predominance test" is generally stated as being the distinguishing test used to determine whether a particular game is a game of skill or a game of chance. ${ }^{119}$ The "predominance test," is defined as follows:

It is the character of the game, and not the skill or want of skill of the player, which determines whether the game is one of chance or skill. A game of chance does not cease to be such because it calls for the

bearing a number from a bottle- that is mere chance. To win, the player must select a numbered ball on the table, and shoot that ball into a hole bearing a number, the total of which numbers must equal the number on the pill; or the player may win, if he shoots his ball into the hole of one Negro, and may win double if he shoots his ball into the hole of the two Negroes.

Id. at 38-39.

113. Id. at 36.

114. Id. at $39-41$.

115. See State v. Eisen, 16 N.C. App. 532, 536 (N.C. App. 1972) (citing Stroupe as the basis for its holding that the lower court "did not err in refusing to rule as a matter of law that the game of blackjack is a game of skill").

116. Stroupe, 238 N.C. at 317.

117. Id.

118. See Cabot \& Hannum, supra note 23.

119. See Stroupe, 238 N.C. at 317. 
exercise of skill, nor does a game of skill cease to be such because at times its result is determined by some unforeseen accident. ${ }^{120}$

Thus, the state of the law at the end of the nineteenth century in North Carolina, rested firmly on the basis that gambling involved "games of chance" and that card games, whether they relied on dealing or drawing the cards, ${ }^{121}$ but especially those that relied in some fashion on the dealing of the cards face down, ${ }^{122}$ fell into this category of games. Stroupe, therefore, formalized the "predominance test" into the analysis of gambling law in North Carolina.

In years to come, challenges to the application of North Carolina gambling laws have centered on the applicability of the predominance test to various forms of games involving mixed games of chance and skill. ${ }^{123}$ In particular, the cases of State v. Eisen and Joker Club, L.L.C. v. Hardin, have served as illustrations of the dominating logic used by defendants seeking to defend themselves against $\S 14-292$. In these two cases, challenges to $\S 14-292$ 's applicability focused on the predominance of skill over chance in the card games of blackjack ${ }^{124}$ and poker. ${ }^{125}$

In particular, State v. Eisen involved an appeal of the defendant's conviction for violating North Carolina gambling laws. ${ }^{126}$ In Eisen, the court addressed the defendant's contention that blackjack ${ }^{127}$ was a game of skill. ${ }^{128}$ In a line of analysis similar to that used thirty-five years later in Joker Club, the court in Eisen used Chief Justice Ruffin's analysis of games of skill versus

120. 38 C.J.S. Gaming $§ 2$ (2008).

121. See Taylor, 111 N.C. 680 at $681-82$.

122. See Gupton, 30 N.C. at 274.

123. For a discussion of mixed games of chance and skill, see Cabot \& Hannum, supra note 23, at $445-46$.

124. See Eisen, 16 N.C. App. at 534 ("Defendant's next contention is that the court committed error in not holding as a matter of law that the game of blackjack is a game of skill").

125. See Joker Club, 643 S.E.2d at 627 ("Plaintiff then filed this action and sought a declaratory judgment that poker was a game of skill, as opposed to a game of chance, and thus not in violation of N.C. GEN. STAT. § 14-292 (2005)").

126. Id.

127. The court in Eisen describes blackjack as follows:

The dealer and all players get one card face down and one card face up. Picture cards have a count of ten and an ace at the election of the player may have a count of one or eleven. The object is to beat the dealer by getting closer to the number 21 than the dealer without exceeding that number. Cards may be drawn by the players and the dealer. Neither the dealer nor the players can anticipate which card will be received when they are dealt an additional card.

Id. at 615 .

128. Id. at 532 . 
games of chance to determine that blackjack was a game of chance. ${ }^{129}$ In making its determination the court held that "the element of chance clearly dominates the element of skill"130 in the game of blackjack. Using its knowledge of the game of blackjack, the Eisen Court, relied heavily on the fact that "[n]either the dealer nor the players can anticipate which card will be received when they are dealt an additional card." 131

While the holding in Eisen may have signaled little other than a willingness by the Court of Appeals of North Carolina to follow precedent laid down before it by the Supreme Court in Gupton, Taylor, and Stroupe, its significance to this article is its discussion of the use of an expert witness by the defendant in an attempt to argue that blackjack was a game where skill predominates over chance. ${ }^{132}$ Although the Eisen Court ultimately excluded the testimony of the defendant's witness, Alan Davis, based on the court's finding that he did not qualify as an expert in the fields of blackjack and mathematics, ${ }^{133}$ the court noted that "[w] hether blackjack as described in the evidence was a game of chance or one of skill was a question for the jury to decide from the evidence and not a question for one who by extensive study and experience has evidently made a career of the game."134 The defendant's attempted use of Davis as an expert witness in order to introduce evidence that blackjack is a game of skill in Eisen can be seen as a precursor to the legal strategy that would be used thirty-five years later in Joker Club.

In essence, Joker Club, L.L.C. v. Hardin is the product of the culmination of the body of North Carolina gambling law from Gupton to Eisen and the phenomenon that is Texas Hold'Em poker. Over the past five years, and in conjunction with the boom of Texas Hold'Em poker on television and the Internet, ${ }^{135}$ legal scholarship ${ }^{136}$ and state case law ${ }^{137}$ have attempted to answer

129. Id.

130. Id. at 535 .

131. Id. at 534 .

132. Id. at 536-37.

133. Id. at 536 .

134. Id.

135. As Josh Tyrangiel writes, "[p]oker was first broadcast on television in 1993, but it wasn't until 2002 that the game became watchable." See Tyrangiel, supra note 64.

136. See Cabot \& Hannum, supra note 23 (surveying state case law and the various classifications between a game of chance or skill the game of poker has in surveyed states); Tselnik, supra note 89; see also, Bennett M. Liebman, Article: Poker Flops Under New York Law, 17 FORDHAM INTELl. PROP. MEDIA \& ENT. L.J. 1 (2006) (discussing the legal issues involved with poker and New York state law). 
the question of whether or not poker is a game predominated by chance or skill. In North Carolina, Joker Club confirms that under North Carolina gambling laws, poker is viewed by courts as a game of chance. ${ }^{138}$

In 2004, Joker Club, L.L.C. intended to open a poker club in Durham, North Carolina. ${ }^{139}$ After notifying the North Carolina Attorney General's office of its intent and obtaining the office's opinion that Joker Club's venture would be illegal under North Carolina state law, Joker Club, filed an action in Durham County Superior Court seeking a declaratory judgment that "poker was a game of skill, as opposed to a game of chance, and thus not in violation of N.C. Gen. Stat. $\S 14-292$ (2005)"140 and seeking a temporary restraining order to prevent $\S 14-292$ 's enforcement. ${ }^{141}$ After the Durham County Superior Court ruled in favor of the defendant attorney general, Joker Club appealed to the Court of Appeals of North Carolina. ${ }^{142}$

In addressing Joker Club's arguments on appeal, ${ }^{143}$ the Court of Appeals considered Joker Club's contention that "the trial court erred in concluding that poker is a game of chance and thus illegal under N.C. Gen. Stat. 14-292 (2005)." 144 In keeping with the trend established in Eisen, ${ }^{145}$ Joker Club presented four witnesses who testified in favor of the position that poker is a game of skill. ${ }^{146}$ However, the sole witness for the defendant testified that "while there was skill involved in poker, luck ultimately prevailed."147 The court established that the testimony of these five witness were evidence that

137. See Garrett v. State, 963 So. $2 \mathrm{~d} 700$ (holding that " 'Texas Hold'em' poker is fundamentally a game of chance, in that the outcome of the game ultimately depends on a random draw of the cards").

138. See Joker Club, 643 S.E.2d 626.

139. Id. at 627 .

140. Id.

141. Id.

142. Id.

143. Joker Club's first assignment of error dealt with the "trial court's failure to enter a Temporary Restraining Order." Id. at 628. The appellate court found that the assignment of error was insufficient because "it is broad, vague, and unspecific." Id.

144. Id.

145. See 16 N.C. App. At 536-37.

146. Joker Club, 643 S.E.2d at 629. Joker Club's witnesses were Roy Cooke, a professional poker player from Las Vegas, Frank Martin, a consultant who runs poker tournaments, Anthony Lee, a casino manager in the Bahamas, and Chris Simmons, a local poker player from North Carolina. Id.

147. Id. Richard Thornell, a North Carolina Alcohol Law Enforcement officer (the N.C. ALE is the division of North Carolina law enforcement entrusted with enforcing $\S 14-292$ ) testified that "he had seen a television poker tournament in which a hand with a $91 \%$ chance to win lost to a hand with only a $9 \%$ chance to win." Id. 
poker is "both a game of skill and chance." 148 Proceeding from this point, the court then used the line of cases previously discussed to establish that North Carolina uses the "predominate-factor test" when determining whether a particular game, in this case poker, is a game where skill or chance predominates. ${ }^{149}$

Where Joker Club is unique, however, is in its analysis of poker in the context of N.C. Gen. Stat. $\S 14-292$. In following the Taylor decision, the Court of Appeals addressed the aspects of poker that led to the court's determination that it was a game of chance. ${ }^{150} \mathrm{In}$ its analysis, the Court of Appeals noted the following:

Poker, however, presents players with different hands, making the players unequal in the same game and subject to defeat at the turn of a card. Although skills such as knowledge of human psychology, bluffing, and the ability to calculate and analyze odds make it more likely for skilled players to defeat novices, novices may yet prevail with a simple run of luck. No amount of skill can change a deuce into an ace. ${ }^{151}$

Ultimately, the court determined that this predomination of chance over skill makes poker a game of chance under N.C. Gen. Stat. $§ 14-292 .{ }^{152}$

\section{CHARITY POKER EVENTS AND NORTH CAROLINA LAW}

Although the North Carolina courts have determined that poker is an illegal game of chance, an area of North Carolina law that has not been explored in depth is the applicability of N.C. Gen. Stat. $\S 14-292$, in the wake of Joker Club, to the increasingly popular tournament-style poker events held within the state. The rise in popularity of poker ${ }^{153}$ has spawned a host of organizations dedicated to capitalizing financially on poker's new fame. ${ }^{154}$ Organizations such as Boston Charity Poker, ${ }^{155}$ Southern Charity Poker, ${ }^{156}$

148. Id.

149. Id. at 130 .

150. Id. at 629 .

151. Id. (emphasis added).

152. Id. at 631 .

153. According to Jeremy Evans of the Tahoe Daily Tribune, "[f]rom 2003 to 2006, the World Series of Poker Main Event in Las Vegas grew exponentially, reaching an all-time high of 8,773 participants in $2006 .$. . "Evans, supra note 66.

154. See Rudoren, supra note 73.

155. Welcome to Boston Charity Poker, Boston Charity Poker, http://www.bostoncharitypoker.com (last visited March 22, 2009). 
and Poker Cares ${ }^{157}$ are entities set up for the sole purpose of organizing and running poker tournaments to raise funds for non-profit organizations. ${ }^{158}$ Other non-profit organizations are simply cutting out the middle man and organizing charity poker events on their own. ${ }^{159}$ Many of these organizations operate within states and jurisdictions where the legality of such tournaments are in question, ${ }^{160}$ while others, such as organizations located in states like Delaware, Maine, or Oregon, where state law allows such activities to occur, operate legally. ${ }^{161}$ Despite only a handful of states having laws directly regulating charitable poker operations, ${ }^{162}$ many non-profit organizations such as the Susan B. Komen Breast Cancer Foundation ${ }^{163}$ are using Texas Hold'Em poker tournaments instead of more traditional methods to raise money. ${ }^{164}$

In North Carolina, an example of an organization that has capitalized on the poker phenomenon to raise money for charitable purposes is Nourish International. ${ }^{165}$ In 2002, Sindhura Citineni began what was then known as Hunger Lunch as a fundraiser to fight hunger. ${ }^{166}$ Over the course of the next three years, her venture grew into what Citineni and a group of UNC students renamed Nourish International in 2005. ${ }^{167}$ Nourish International has evolved from a student group at the University of North Carolina at Chapel Hill with dreams of ending hunger, to a "non profit that connects college students from

156. Wild Bill's Charity Poker Tournaments, http://wbcpoker.com (last visited March 22, 2009).

157. Poker Cares, http://pokercares.com (last visited March 22, 2009).

158. An examination of these organizations' websites serves as an illustration of these entities purposes. Boston Charity Poker's mission is stated as being, "to ensure your participants have a great time, and your charity achieves its fundraising goals." Welcome to Boston Charity Poker, supra note 155. Poker Cares states its mission as being "committed to helping facilitate the growth of Charity Poker Tournaments that are being held all over the world and raising funds for worthy causes." Poker Cares, supra note 157.

159. See Rudoren, supra note 73 (reporting that the National High School Gymnastics Coaches Association made $\$ 3,820.42$ hosting its own casino-style charity event).

160. Id. at 2. See also Colo. Rev. STAT. 12-9-101 - 12-47.1-903 (2008); S.C. CODE ANN. §§ 3356-10 - 33-56-200 (2009); KY. REV. STAT. $\$ \S 238.500$ - 238.995 (2009); 61 PA. CODE $\$ \$ 901.501-$ 901.535 (2009).

161. Rudoren, supra note 73, at 2. See also DEL. CODE ANN. 28, $\S$ 1801-1835 (2008); OR. REV. STAT. $\$ \$ 464.250$ - 464.995 (2007). See also Steward, supra note 73.

162. See DEl. CODE ANN. 28, §§ 1801-1835; OR. REV. STAT. \$167.118.

163. See Rudoren, supra note 73.

164. Id.

165. Welcome to Nourish International, Nourish International, http://nourishinternational.org (last visited March 22, 2009).

166. See The History of Nourish. Nourish International, http://www.nourishinternational.org/ about/history.php (last visited March 1, 2009).

167. Id. 
universities around the nation to development projects abroad."168 Nourish International pairs ambitious, socially active college students with non-profit and charitable organizations in order to raise funds through "ventures" organized by and aimed toward college students. ${ }^{169}$

One such "venture" has been a charity poker tournament held under the name "Hold'Em For Hunger" (hereinafter "HEFH") and sponsored by Nourish International. ${ }^{170}$ In April of 2007, Nourish International sponsored the third edition of HEFH in conjunction with World Tavern Poker. ${ }^{171}$ The charitable poker tournament, which was set up in a Texas Hold'Em format, was expected to bring in between four to five hundred participants. ${ }^{172}$ A ticket to the event cost $\$ 25$, providing each participant with admission, an event $t$-shirt, a catered meal, a local travel agency voucher worth $\$ 25$, and an entry into a raffle to win an Apple iPod. ${ }^{173}$

In the wake of Joker Club, however, the legality of tournaments such as HEFH must be examined under North Carolina law. According to N.C. Gen. Stat. $§ 14-292$,

any person or organization that operates any game of chance or any person who plays at or bets on any game of chance at which any money, property or other thing of value is bet, whether the same be in stake or not, shall be guilty of a Class 2 misdemeanor. ${ }^{174}$

As discussed previously, Joker Club stands for the proposition that courts in North Carolina view poker, and presumably Texas Hold'Em poker, ${ }^{175}$ as a game of chance under N.C. Gen. Stat. $\S 14-292$. Although, the organizers of Hold'Em for Hunger may argue that Texas Hold'Em is a game predominated by skill, North Carolina state law appears to be settled against that position.

Applying the statute to the HEFH format provides a bleak outlook on the legality of the tournament in its current form under current North Carolina

168. Id.

169. Id. These "ventures" according to Nourish International "cater to the student market, meaning they provide a good or service that other students are willing to purchase for the inherent value of the good or service." Id.

170. See Fiedler, supra note 6.

171. Id.

172. Id.

173. Id.

174. N.C. GEN. STAT. $§ 14-292$.

175. Although the Court of Appeals does not use the specific term "Texas Hold'Em" anywhere in the case, the defendant's witness testimony suggest that the game of poker "he had seen on television" was Texas Hold'Em. See Joker Club, 643 S.E.2d at 629. 
law. If poker is indeed a game of chance, then under N.C. Gen. Stat. § 14-292, any person or organization, in this case, Nourish International, World Tavern Poker, or any other person or organization that operates a charitable poker tournament such as HEFH in North Carolina may be charged with a Class 2 misdemeanor. Additionally, under a strict interpretation of the statute, "any person who plays at or bets at a game of chance," 176 in this case any student or other participant who takes part in the charitable tournament, whether or not the poker chips they use have any actual value, would be in violation of the statute. Going even further, if such tournaments are forbidden by North Carolina state law, then, depending on where the tournament is held, the establishment hosting the event may also be criminally liable. ${ }^{177}$

However, support for such a strict reading of the statute so as to prohibit charitable poker tournaments in North Carolina may not be forthcoming from state prosecutors. ${ }^{178}$ In an article in the Raleigh News \& Observer regarding the inconsistency of enforcement in North Carolina's gambling laws as applied to poker tournaments, Wake County District Attorney Colon Willoughby acknowledged the illegality of charitable poker tournaments, but stated that the District Attorney's Office "tries to use 'common sense' when the proceeds are clearly for charitable purposes or where the purpose is to fill a restaurant or bar with patrons." 179 The article contrasted Mr. Willoughby's position on the matter with that of North Carolina Alcohol Law Enforcement Director Mike Robertson. ${ }^{180}$ Mr. Robertson, when asked his opinion on the legality of a recent poker tournament held at a restaurant in Raleigh, also acknowledged that "if there was an exchange of cash or other prizes such as a television and [a] vacation to Cabo San Lucas, then the tournament was illegal."181 Mr. Willoughby, however, suggested that the legislative intent, in his opinion, was

176. N.C. GEN. STAT. § 14-292.

177. See N.C. GEN. STAT. $\$ 14-293$ (codifying the penalty for "allowing gambling in houses of public entertainment"). Whether the University of North Carolina would be liable for allowing Hold'Em for Hunger to be staged on university grounds is unknown. If the event was staged at a restaurant or bar, as many poker tournaments in North Carolina are, then those establishments might be in guilty of a Class 2 misdemeanor and in danger of losing their liquor licenses if they have a license.

178. See McDonald, supra note 75 .

179. Id.

180. Id.

181. Id. 
not to encourage law enforcement in North Carolina to focus on charitable or tavern $^{182}$ poker, but instead illegal gambling halls. ${ }^{183}$

Such disparity between members of North Carolina's legal and law enforcement communities may lead to increased confusion among organizations seeking to run charitable poker tournaments. As Willoughby suggests, the intent of N.C. Gen. Stat. $\S 14-292$ is to criminalize illegal gambling and "gambling houses where people pay an entry fee to play and the proprietor takes a cut of the pot and profits from food and drinks."184 The structure of charitable tournaments such as Hold'Em For Hunger, however, parallels what Willoughby suggests $\S 14-292$ is meant to prohibit.

For example, HEFH charges an entry fee of $\$ 25 .{ }^{185}$ Were this fee to be pooled into a larger pot, and then given to the winner or divided among certain finishing positions, the tournament, despite its charitable underpinnings, would most certainly be illegal under North Carolina law. Yet, HEFH does not operate in this manner and instead offers prizes such as high definition television sets and gift certificates to restaurants. Although none of the HEFH entry fee is put toward purchasing prizes, State $v$. DeBoy, ${ }^{186}$ suggests that the actual legality of HEFH may turn on requiring an entry fee in order to participate and the issue of the players betting, despite whether or not their bets have any real monetary value.

In DeBoy, ${ }^{187}$ the defendant owned a store in Raleigh where he offered his customers a chance to roll dice and win a turkey for ten cents per chance. ${ }^{188}$ In order to win, the customer that threw the highest number took the turkey. ${ }^{189}$ The DeBoy Court, began its decision by stating that "[i]f several parties each put up a piece of money and then decide by throwing dice who shall have the aggregate sum, or 'pool,' this is unquestionably a game of chance. The sum put up by each is his bet and the pool gamed for is the stake."190 Although the

182. The reference to "tavern" poker is poker tournaments that are run in very much the same manner as are many charitable poker toumaments, the difference being simply the location in which the tournament is held and the motivation of the host. Often tavem poker tournaments are held for promotional purposes to bring in customers who then spend money on food and drink while playing poker.

183. McDonald, supra note 75 ; see also, McDonald, supra note 3 .

184. See McDonald, supra note 75.

185. See Fiedler, supra note 6.

186. 117 N.C. 702 (Sup. Ct. 1895).

187. Id.

188. Id.

189. Id.

190. Id. at 704 . 
court noted that the defendant "chose to style the transaction a raffle, and it is contended that a raffle is a kind of lottery and hence not a game of chance,"191 the court rejected this argument, by stating that "a person cannot be said to play at a lottery." 192 In holding the defendant liable for gambling, the court held that "the transaction was simply gaming with dice, with ten-cent bets and for a turkey as a 'pool.' "193

The DeBoy Court also addressed what at the time was "the long prevailing custom of 'shooting for beef" 194 where participants paid for "the privilege or so-called 'chance' of shooting for the prize."195 The court distinguished this form of competition from gambling, however, by stating that "[t]hese are trials of skill, which the law has never discouraged, and not games of chance in any sense." 196 The court went on to note that the 1895 form of what is now $\S 14$ 292 did not "prohibit the social diversions in which the hostess offers prizes for the most successful player at cards or other games. In such cases, though they are games of chance, the players bet nothing. They lose nothing if unsuccessful, and pay nothing for the chance of winning." 197

Viewing the structure of HEFH under the logic and holding of DeBoy, the current format of HEFH may be illegal. For example, simply substituting "throwing of dice" with "Texas Hold'Em poker" and "turkey" with "42-inch DLP HDTV" illustrates how the holding in DeBoy might be applied to the current state of HEFH. Although HEFH participants pay an entry fee, but do not actually bet anything of value during a HEFH hand of poker, and there are no cash prizes awarded, the holding in DeBoy would still find the tournament in violation of the statute. For instance, in substituting the above phrases into DeBoy, "[i]f [hundreds of college students] put up [\$25] and then decide by [playing Texas Hold'Em poker] who shall have the [42-inch DLP HDTV], this is unquestionably a game of chance." Additionally, "the [\$25] put up by each is his bet and the [42-inch DLP HDTV] is the stake." Thus, it does not matter where prize money comes from or what the actual value of the prize would be, but rather that the law makes "any person who plays at or bets on any game of

191. Id.

192. Id.

193. Id.

194. Id. at 705 . The court notes that the 1891 version of the statute is virtually identical to that of the current $\$ 14-292$.

195. Id.

196. Id.

197. Id. 
chance at which any money, property or other thing of value is bet, whether the same be in stake or not," 198 a crime.

Even if Joker Club had been decided differently and poker was held to be a game of skill, then HEFH's format would still be no different than DeBoy's "shooting for beef." 199 Unfortunately, the final three sentences of DeBoy do not help HEFH's cause. While the court notes that the statute, which in its 1891 form is virtually identical to that of $\S 14-292,{ }^{200}$ does not "prohibit the social diversions in which the hostess offers prizes for the most successful player at cards or other games,"201 it qualifies that statement by pointing out that "in such cases, though they are games of chance, the players bet nothing. They lose nothing if unsuccessful, and pay nothing for the chance of winning." 202 Under this logic and knowing that North Carolina courts under Joker Club view poker as a game of chance, it is difficult to argue that under HEFH's format the players "lose nothing if unsuccessful, and pay nothing for the chance of winning." 203 Therefore, the $\$ 25$ entry fee may, as viewed under DeBoy, be the largest obstacle to HEFH's legality.

\section{CONCLUSION}

Given the current state of gambling law in North Carolina, staging charitable fundraisers in poker tournament formats is illegal. The line of North Carolina case law has established that poker is a game predominated by chance, and thus, prohibited by N.C. Gen. Stat. $\S 14-292$. Due to this determination, various organizations, including $\mathrm{HEFH}$, are in danger of violating North Carolina law when charging entry fees or staging fundraising ventures in a poker format. Nourish International canceled the $2008 \mathrm{HEFH}$ tournament "in the face of concerns about the legality of the contest."204

198. N.C. GEN. STAT. § 14-292.

199. Deboy, 117 N.C. at 705.

200. The DeBoy court stated:

Whatever defects there were in the law of gambling were intended to be cured by Acts 1891, ch. 29 , which makes it "unlawful for any person to play at any game of chance at which money, property or other thing of value is bet, whether the same be at stake or not, and those who play and those who bet thereon shall be guilty of a misdemeanor.

Id. at 705 .

201. Id. at 705.

202. Id.

203. Id.

204. See Brian Austin, Hold'Em for Hunger Canceled for Legal Issue, THE DAILY TAR HEEL, March 20, 2008, available at http://media.www.dailytarheel.com/media/storage/paper885/news/2008/ 
This will likely be an on-going issue in North Carolina with organizations such as Chips for Charity planning charitable poker tournaments in 2009. ${ }^{205}$ While these organizations and their operators may be willing to risk the discretion of North Carolina law enforcement officials, any future for legal charitable poker in North Carolina seems clearly to lie in the hands of the legislature. Charitable organizations in North Carolina may want to lobby state representatives to sponsor and adopt legislation such as that in Delaware which would legalize charitable poker tournaments. ${ }^{206}$ In the meantime, the precedent in Joker Club may influence other states that are currently litigating whether poker is a game of skill or chance.

\section{ABOUT THE AUTHORS}

BLAKE GRIFFIN is a native of Boone, North Carolina, and a dual degree candidate in Law and Sport Administration at the University of North Carolina at Chapel Hill. He also earned a B.A. in Public Policy in 2003 from the University of North Carolina at Chapel Hill. The co-winner of the 2008 Bernard Maloy Graduate Research Paper Award sponsored by the Sport and Recreation Law Association, Blake is a former college soccer player who hopes to pursue a career as an attorney working in the sport industry.

BARBARA OSBORNE, J.D. is an Associate Professor in Exercise and Sport Science (Sport Administration) and an Adjunct Professor in the School of Law at the University of North Carolina at Chapel Hill. Prior to her appointment at UNC, Barbara worked for 14 years as an athletics administrator in intercollegiate athletics. She has also had experience as a coach, public relations coordinator, television sports commentator, publisher and sports information director.

\section{REFERENCES}

Aherns, F. (2006, October 14). New law cripples internet gambling; banks are barred from handling transactions, Washington Post, A1.

Allowing gambling in houses of public entertainment; penalty, N.C. Gen. Stat. § 14-293 (2009).

03/20/University/Hold-em.For.Hunger.Canceled.For.Legal.Issue-3276414.shtml (last visited Marck. 1, 2009).

205. See Chips for Charity, http://www.chipsforcharity.org/ (last visited March 1, 2009).

206. DEL. CODE ANN. 28, $\S \S 1801-1835$. 
Alvarez, A. (2001). Poker: Bets, bluffs, and bad beats. San Francisco: Chronicle Books. Pg. 32.

American Gaming Association (2006). State of the states: The AGA survey of casino entertainment. Retrieved April 4, 2008, from http://www. americangaming.org/assets/files/2006_Survey_for_Web.pdf

Austin, B. (2008, March 20). Hold'Em for hunger canceled for legal issue, The Daily Tar Heel. Retrieved March 22, 2009, from http://media.www. http://www.dailytarheel.com/2.1383/1.156002-1.156002

Balko, R. (2006, February 8). Overkill: The latest trend in policing. Chicago Daily Law Bulletin, 6.

Bellin, A. (2002). Poker nation: A high-stakes, low-life adventure into the heart of a gambling country. New York: Harper Collins.

Bingo, N.C. Gen. Stat. $\S \S 14-309.5$ - 14-309.15 (2009).

Bingo and Raffles Law, Colo. Rev. Stat. 12-9-101 - 12-47.1-903 (2008).

Cabot, A. \& Hannum, R. (2005). Poker: Public policy, law, mathematics, and the future of an American tradition. Thomas M. Cooley Law Review, 22(3), 443513.

Charitable Gaming, Ky. Rev. Stat $§ § 238.500$ - 238.995 (2009).

Chips for Charity. (n.d.). Retrieved March 1, 2009, from http://www. chipsforcharity.org/

C.J.S. Gaming $§ 2$ (2008).

Dummet, M. (1980). The game of tarot: From Ferrara to Salt Lake City. London: Duckworth.

Evans, J. (2007, November 15). Growing or declining? Tahoe Daily Tribune. Retrieved April 4, 2008, from http://www.tahoedailytribune.com/article/ 20071115/SPORTS/111150068

Fiedler, A. (2007, March 30). Students chip in for poverty. The Daily Tar Heel. Retrieved March 22, 2009, from http://www.dailytarheel.com/2.1383/ 1.163955-1.163955

Gambling, N.C. Gen. Stat. § 14-292 (2009).

Games Administration, Or. Rev. Stat. $§ § 464.250$ - 464.995 (2007).

Garrett v. State, 963 So. 2d 700 (Ala. Crim. App. 2007).

Girdwood, R. S. (2002). Comment: Place your bets. . on the keyboard: Are internet casinos legal? Campbell Law Review, 25(1), 135-150. 
Grotenstein, J. \& Reback, S. (2005). All in: The (almost) entirely true story of the World Series of Poker. New York: Thomas Dunne Books.

History of Texas Hold'Em. (n.d.). World Casino Directory. Retrieved April 4, 2008, from http://www.worldcasinodirectory.com/texasholdemhistory.htm

Johnson, A. (2006, May 17). Know when to hold 'em; prosecutor exercises discretion in poker prosecution. The Indiana Lawyer, 1.

Joker Club, L.L.C. v. Hardin, 643 S.E.2d 626 (N.C. App. 2007).

Keeping gaming tables, illegal punchboards or slot machines, or betting thereat, N.C. Gen. Stat. § 14-295 (2009).

Kelly, J. (2006). Poker: The very American career of the card game you can learn in 10 minutes and work on for the rest of your life. American Heritage, 57, 38. Retrieved April 4, 2008, from http://www.americanheritage.com/ articles/magazine/ah/2006/6/2006_6_38.shtml

Liebman, B. M. (2006). Article: Poker flops under New York law. Fordham Intellectual Property, Media \& Entertainment Law Journal, 17(1), 1-38.

Local Option Small Games of Chance, $61 \mathrm{~Pa}$. Code $\S \S 901.501$ - 901.535 (2009).

McDonald, T. (2007, September 11). Casino raid netted big poker winner. The News \& Observer (Raleigh). Retrieved April 4, 2008, from http://www.newsobserver.com/news/crime_safety/story/699914.html

McDonald, T. (2007, September 28). Poker tourneys gamble with law. The News \& Observer (Raleigh). Retrieved April 4, 2008, from $\mathrm{http}: / / \mathrm{www}$. newsobserver.com/front/story/719095.html

Mission Statement. (n.d.). Poker Players Alliance. Retrieved March 1, 2009, from http://pokerplayersalliance.org/pdf/PPAMissionStatement.pdf

Nesbitt, J. (2006, March 30). North Carolina gambles lottery won't fade again. The News \& Observer (Raleigh). Retrieved April 4, 2008, from http://www.newsobserver. com/701/story/423350.html

No Limit Texas Hold'em Poker, Del. Code Ann. 28, §§ 1801-1835 (2008)

North Carolina State Lottery Act, N.C. Gen. Stat. §§ 18C-101 - 18-172 (2009).

Nourish International. (n.d.a.). The history of Nourish International. Retrieved April 7, 2009, from http://www.nourishinternational.org/ about/history.php

Nourish International. (n.d.b.). Welcome to Nourish International. Retrieved February 13, 2009, from http://www.nourishinternational.org/ 
Parlett, D. (2001). The Oxford guide to card games. Oxford: Oxford University Press.

Poker.com. (n.d.). The history of poker. Poker.com. Retrieved July 13, 2008, from http://www.poker.com/history-of-poker.htm

Poker Cares Homepage. (n.d.). Retrieved July 13, 2008, from http://pokercares.com/

Poker Players Alliance. (n.d.). Retrieved July 13, 2008, from http://www. pokerplayersalliance.org/

Poker Rules. (n.d.). Texas Hold'Em. Retrieved March 22, 2009, from http://www.pokerpages.com/pokerinfo/rules.htm?content=1 \#texas

Rudoren, J. (2006, February 6). Seeking new sources of money, charities get in on poker craze. New York Times, A1.

South Carolina Solicitation of Charitable Funds Act, S.C. Code Ann. §§ 33-5610 - 33-56-200 (2009).

State v. Eisen, 16 N.C. App. 532 (N.C. App. 1972).

State v. Deboy, 117 N.C. 702 (Sup. Ct. 1895).

State v. Gupton, 30 N.C. 271 (Sup. Ct. 1848).

State v. Taylor, 111 N.C. 680 (Sup. Ct. 1892).

State v. Stroupe, 238 N.C. 34 (Sup. Ct. 1953).

Steward, C. K. (2006, March 5). Cashing in when the chips are down: Charities, nonprofits ride the wave of poker popularity to raise money. MetroWest Daily News. Retrieved November 10, 2008, from http://www.givingmedianetwork.com/picsaboutus/metro_west.pdf

The Unlawful Internet Gambling Enforcement Act, Pub. L. No. 109-347, 120 Stat. 1952 (2006).

Thompson, E. (2007, Sept. 11). Poker champ netted in NC gambling bust, Associated Press. Retrieved March 24, 2009, from http://www. pokerroomreview.com/NewsWire/0837/Poker + Champ + Netted + in $+\mathrm{NC}+\mathrm{Ga}$ mbling+Bust.aspx

Tselnik, M. A. (2007). Note: Check, raise, or fold: poker and the unlawful Internet Gambling Enforcement Act. Hofstra Law Review, 35(3), 1617-1670.

Tyrangiel, J. (2003, September 1). Decks, lies \& videotape; with cameras peeking at players' cards - and some bizarre contestants-poker is a hot spectator sport. Time, 62 . 
Wild Bill's Charity Poker Tournaments. (n.d.). Retrieved March 22, 2009, from http://wbcpoker.com

U.S. Const. Amend. X.

Wallace, F. (1968). Poker: A guaranteed income for life by using the advanced concepts of poker. Wilmington, DE: I \& O Publishing Company.

Welcome to Boston Charity Poker. (n.d.). Boston Charity Poker. Retrieved April 4, 2008, from http://www.bostoncharitypoker.com/home

World Series of Poker History. (n.d.). World Series of Poker. Retrieved November 23, 2007, from http://espn.go.com/eoe/wsop/history.html 